\title{
A STUDY OF MARKET ANALYSIS OF PESTICIDES
}

\section{ANAM CHAUDHARY}

Student, Institute of Agri-Business Management, Swami Keshwanand Rajasthan Agricultural University,

Bikaner Rajasthan, India

\begin{abstract}
There are good emerging trends and solutions for sustainable crop protection which include crop protection chemicals, agronomy, fertigation, seed treatment, biotechnology development etc. The next generation agriculture in the country will have to encompass all such possible solutions using the best mode in a given scenario. The sector faces many challenges and solution to the same can lead to India becoming a global manufacturing hub of quality crop protection chemicals. A study was conducted for market analysis of pesticides. The ultimate aim of the research was to analyze the future perspective of business to formulate a competitive strategy to boost business. It includes the assessment of the market size of pesticides and market share, It also underwent the study of awareness level about pesticides. It also came up with the findings of stakeholders' perception of promotional activities for pesticide products. Findings of this study will help the pesticide companies in formulating their marketing strategies and to serve the farming community in a better way.

KEYWORDS: Awareness, Buying Behaviour, Distributors, Farmers, Market Size, Market Share, Perception, Pesticides and Promotional Activities
\end{abstract}

Received: Sep 14, 2018; Accepted: Oct 04, 2018; Published: Oct 17, 2018; Paper Id.: IJASRDEC20182

\section{INTRODUCTION}

India is being an Agrarian economy. Optimum utilization of agri-inputs is necessary to achieve food security and sustainability of farm business. Adoption of modern farming techniques, high yielding varieties, farm mechanization has made a significant contribution towards raising production. At the same time the intense cultivation of high yielding varieties, monoculture of commercially important crops and overlapping of cropping season have resulted in high incidences of pests and diseases. In the process of development of agriculture, pesticides have become an important tool as a plant protection agent for boosting food production. In India, on an average, 33 per cent of crop loss occurs due to pests and diseases and runs to an estimated Rs. 200 billion. Pesticides are under-utilized in agriculture despite the generally held believe that these inputs are substantially over-utilized (Lansink and Silva, 2004). The worldwide consumption of pesticides has reached 2.6 million metric tons. Of this, 85 per cent is used in agriculture (Wilson and Tisdell, 2001). Although the largest volume of pesticide use is in developed countries, its use is growing rapidly in developing countries. Pesticides are essentially an ally in the farmers struggle to protect their crops. Their use is high in regions with good irrigation facilities and in areas where commercial crops are grown. They are also increasingly employed for public health purposes and for domestic use. Pesticides are unique chemicals as they are intrinsically toxic for several biological targets, are deliberately spread into the environment, and their toxicity has a limited species selectivity. The Indian crop protection market is dominated by Insecticides, which form almost 60 per cent of the domestic crop protection 
chemicals market. The major applications are found in rice and cotton crops. Fungicides and Herbicides are the largest growing segments accounting for 18 per cent and 16 per cent respectively of total crop protection chemicals market respectively (A Report on Indian Agrochemicals Industry 2016). Pesticides can play a major role in enhancing productivity and crop protection post-harvest. Nearly 50\% of the world labor force is employed in agriculture. Over the last 50 years, agriculture has deeply changed with a massive utilization of pesticides and fertilizers to enhance crop protection and production, food quality and food preservation. Pesticides are also increasingly employed for public health purposes and for domestic use (Maroni et al. 2006). They are diluted in recommended doses and applied on seeds, soil, irrigation water and crops to prevent damage from pests, weeds, and diseases. Pesticides with a solubility of $10 \mathrm{ppm}$ or higher are lost mainly in the water phase of runoff, and erosion control practices will have little effect on such losses (Wauchope, R. D. 1978). Insecticides are the largest sub-segment of pesticides with 60 per cent market share, whereas herbicides with 16 per cent market share are the fastest growing segment in India. India is the fourth largest global producer of agrochemicals after the US, Japan, and China. This segment generated a value of USD 4.4 billion in FY15 and is expected to grow at 7.5 per cent per annum to reach USD 6.3 billion by FY20(A Report on Indian Agrochemicals Industry 2016).

This research has been done under the sponsorship of Excel Crop Care Limited in Bikaner and Hanumangarh district of Rajasthan. This project is emphasized exclusively on pesticides. In this study farmers and distributors are included. This study is about the study of pesticide market in Bikaner and Hanumangarh and to come out with some fruitful findings.

\section{Introduction to the Study Area}

The area covered was part of Rajasthan which comes under Bikaner and Hanumangarh districts. They have varied types of soils and climatic conditions. The soils of Bikaner district are predominantly light textured, weak - structured, sand to sandy loam with the clay content. Arid climate with low rainfall, high temperature, and high evaporation losses has resulted in the physical and mechanical disintegration of the parent material giving rise to predominance of coarse fraction in the soil. Very little chemical weathering has taken place and the development of soil is mostly indistinct. Soils are generally of the deserted type with poor fertility status and very low water retention capacity. Groundnut, Moong, Fenugreek, Gram are the main crops of Bikaner. Tubewell is the only means of irrigation in Bikaner. Hanumangarh district is covered by arid soils which are characterized by alluvial soils. These soils are loamy in character. Principle crops are Groundnut, Cotton, Paddy etc. Principal means of irrigation in the district is through canals, though some areas are irrigated by wells/ tube wells. The districts were selected on the basis of judgmental sampling technique in which a cluster of the area is selected which gives maximum representations of the product sales in the state under the regional headquarter.

\section{Objectives}

- To study the market size of pesticides and market share of Excel products in the study area

- To study awareness level about pesticides

- To study stakeholder's perception of promotional activities for pesticide products 


\section{RESEARCH METHODOLOGY}

\section{Study Area}

The entire study was carried out in two districts of Rajasthan i.e. Bikaner and Hanumangarh.

\section{Collection of Data}

- Primary Data: The primary data sources were distributors and farmers in the selected areas of Bikaner and Hanumangarh. The methodology for the collection of primary data involved interview schedules through prepared questionnaires.

- Secondary Data: The secondary data sources included the web portals and company personnel.

\section{Research Design}

Descriptive research was carried out in this project.

\section{Sampling Technique}

- Judgmental Sampling: Distributors and districts were selected as per the instructions of the company.

- Convenience Sampling: Farmers were selected on the convenience basis.

Sample Units and Size

Table 1: Different Stakeholders Involved in the Study

\begin{tabular}{|l|c|}
\hline Sample Unit & Size \\
\hline Farmers & 200 \\
\hline Distributors & 30 \\
\hline Total & $\mathbf{2 3 0}$ \\
\hline
\end{tabular}

\section{Research Instrument}

A Pre-structured questionnaire was prepared for distributors and farmers consisting of both closed-ended and open-ended questions.

\section{Analytical Technique}

Cross-tabulation is applied to measure awareness.

\section{FINDINGS AND ANALYSIS}

To study the Market Size of Pesticides and Market Share of Excel Products in the Study Area

Table 2: Estimation of Total Market Size \& Market Share

\begin{tabular}{|c|c|c|c|}
\hline \multicolumn{3}{|c|}{ Total No. of Distributors } & 300 \\
\hline \multicolumn{3}{|c|}{ Total no. of Excel distributors } & 30 \\
\hline \multicolumn{3}{|c|}{ Total market size } & 9882 lakh (approx.) \\
\hline \multicolumn{3}{|l|}{ Market share of Excel } & 1550 lakh (15.65 per cent) approx. \\
\hline \multicolumn{3}{|c|}{ Turnover of Excel in 2016-17 } & 474 lakh \\
\hline \multirow{2}{*}{ Total turnover in $2016-17$} & \multirow{2}{*}{4245 lakh } & Wholesale & 32 per cent \\
\hline & & Retail & 68 per cent \\
\hline \multirow{2}{*}{\multicolumn{2}{|c|}{ Mode of payment }} & Cash & 27 per cent \\
\hline & & Credit & 73 per cent \\
\hline
\end{tabular}

Source: Primary data collected by the author through pre- structured schedule 
Above table 2 shows that total market size of pesticides was approximately 9882 lakh (approx.) in Bikaner \& Hanumangarh district of Rajasthan. There were many companies in pesticide market of Bikaner \& Hanumangarh and Excel Crop Care had 1550 lakh (approx.) with 15.65 per cent share in pesticides.

\section{To Study Awareness Level about Pesticides}

Farmers' Profile: To study the awareness level we first need to know the profile of farmers which is as follows:

Table 3: Computation of Age

\begin{tabular}{|c|c|c|c|}
\hline \multirow{2}{*}{ S. No. } & \multicolumn{3}{|c|}{ Age } \\
\cline { 2 - 4 } & Category & Frequency & Percentage \\
\hline 1 & $<30$ years (Early Young) & 21 & 10 \\
\hline 2 & $30-<45$ years (Late Young) & 100 & 50 \\
\hline 3 & $45-<60$ years (Middle) & 45 & 23 \\
\hline 4 & $=>60$ years (Old) & 34 & 17 \\
\hline & Total & $\mathbf{2 0 0}$ & $\mathbf{1 0 0}$ \\
\hline
\end{tabular}

Source: Primary data collected by author through pre- structured schedule

From table 3 it can be inferred that majority of the sample size belonged to late young and middle age group. So we can say that there were very less young farmers.

Table 4: Computation of Education

\begin{tabular}{|c|c|c|c|}
\hline \multirow{2}{*}{ S. No. } & \multicolumn{3}{|c|}{ Education } \\
\cline { 2 - 4 } & Category & Frequency & Percentage \\
\hline 1 & Illiterate & 38 & 19 \\
\hline 2 & Primary & 66 & 33 \\
\hline 3 & Secondary & 54 & 27 \\
\hline 4 & Senior Secondary & 30 & 15 \\
\hline 5 & Graduate/PG & 12 & 6 \\
\hline & Total & $\mathbf{2 0 0}$ & $\mathbf{1 0 0}$ \\
\hline
\end{tabular}

Source: Primary data collected by author through pre- structured schedule

Table 5: Computation of Land Holding

\begin{tabular}{|c|c|c|c|}
\hline \multirow{2}{*}{ S. No. } & \multicolumn{3}{|c|}{ Land Holding } \\
\cline { 2 - 4 } & Land/ha & Frequency & Percentage \\
\hline 1 & $0-1$ ha & 5 & 2 \\
\hline 2 & $>1-5$ ha & 22 & 11 \\
\hline 3 & $>5-10$ ha & 58 & 29 \\
\hline 4 & $>10$ ha & 115 & 58 \\
\hline & Total & $\mathbf{2 0 0}$ & $\mathbf{1 0 0}$ \\
\hline
\end{tabular}

Source: Primary data collected by author through pre- structured schedule

In the tables 4 and 5 it is shown that only a few farmers were the illiterate majority of the farmers were literate. So it can be inferred that they were able to understand the pros and cons of using pesticides, a quantity of pesticides to be used, a method of application etc. In terms of land holding majority of the farmers were having more than 10 hectare land. 
Table 6: Use * Aware Cross Tabulation

(Awareness Level among Farmers)

\begin{tabular}{|c|c|c|c|c|}
\hline \multicolumn{2}{|c|}{} & \multicolumn{2}{c|}{ Aware } & \multirow{2}{*}{ Total } \\
\cline { 3 - 4 } \multicolumn{2}{|c|}{} & Yes & No & \\
\hline \multirow{2}{*}{ Use } & Yes & 148 & 23 & 171 \\
\cline { 2 - 5 } & No & 29 & 0 & 29 \\
\hline \multicolumn{2}{|c|}{ Total } & $\mathbf{1 7 7}$ & $\mathbf{2 3}$ & $\mathbf{2 0 0}$ \\
\hline
\end{tabular}

Source: Primary data collected by author through pre- structured schedule

The above table 6 is showing that 88.5 per cent farmers were aware and 11.5 per cent farmers were unaware about pesticides while 85.5 per cent farmers were using pesticides and 14.5 per cent farmers were not using it. Some farmers were aware but not using the products as they were adopting organic farming due to the effect of Pramparagat Krishi Vikas Yojana and some farmers were not aware but using the product because they were working as kashtkar in the field of landlords because there was a Kashtkari system so they use whatever provided by the landlords.

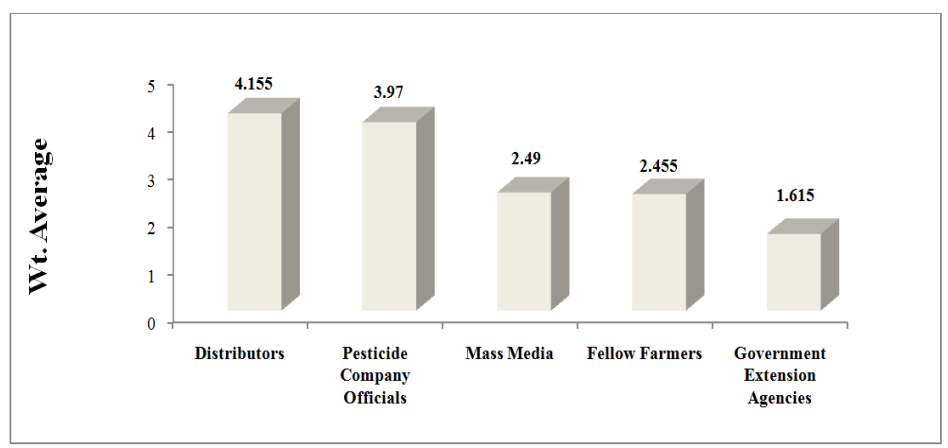

Source: Primary data collected by author through pre- structured schedule

Figure 1: Perception of Farmers about the Sources of Awareness

In this figure 1, it is shown that distributor was the major source of awareness among farmers as farmers easily rely on distributors so whatever they told to farmers they just believe on it. Pesticide company officials were also preferred by some farmers as there were many company officials approaching them so they also gave some information regarding the pesticide products to farmers. Government extension agencies were the least preferred source of awareness by the farmers because they thought that government extension agencies do not approach them.

\section{To Study Stakeholders' Perception about Promotional Activities for Pesticide Products}

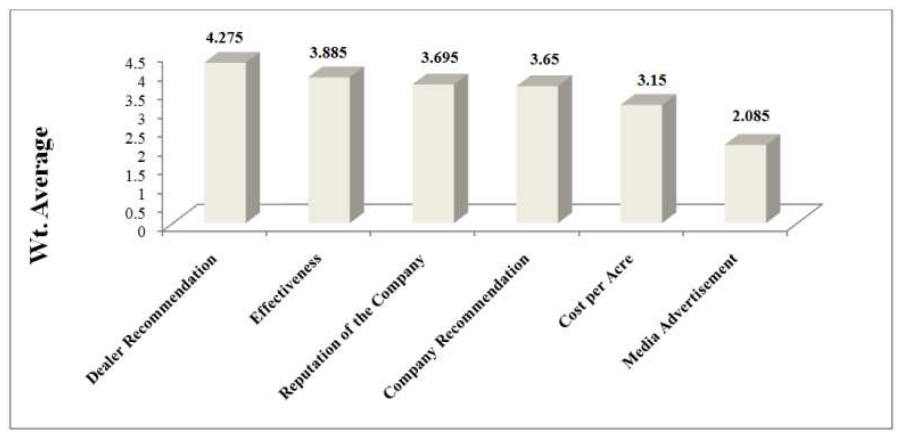

Source: Primary data collected by author through pre- structured Schedule

Figure 2: Farmers' Preference Regarding the Purchase of Pesticides 
As shown in figure 2 majority of the farmers purchased the pesticide products on dealer recommendation only. They have a huge impact of dealer recommendation on their purchasing decision. Therefore most company targeted dealers for increasing their sales. Some farmers also said that they consider the effectiveness of the product while purchasing and some farmers said that go for the reputation of the company while purchasing. Only a few farmers preferred media advertisement while purchasing pesticide products because there was less impact of media advertisements in villages.

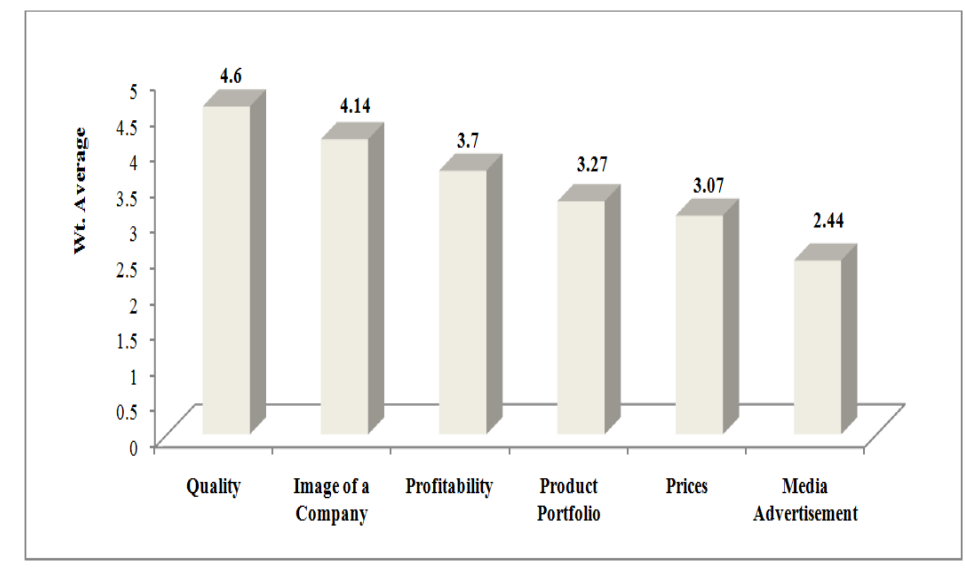

Source: Primary data collected by author through pre- structured schedule

\section{Figure 3: Distributor's Preference Regarding Dealing with Pesticide Companies}

As shown by figure 3 distributors preferred the quality of the products the most and the image of the company was also preferred by the majority of the distributors while dealing. But some farmers said that profitability is also a factor they consider before dealing with any pesticide company. Distributors said that they least consider prices of the products and media advertisements done by the company.

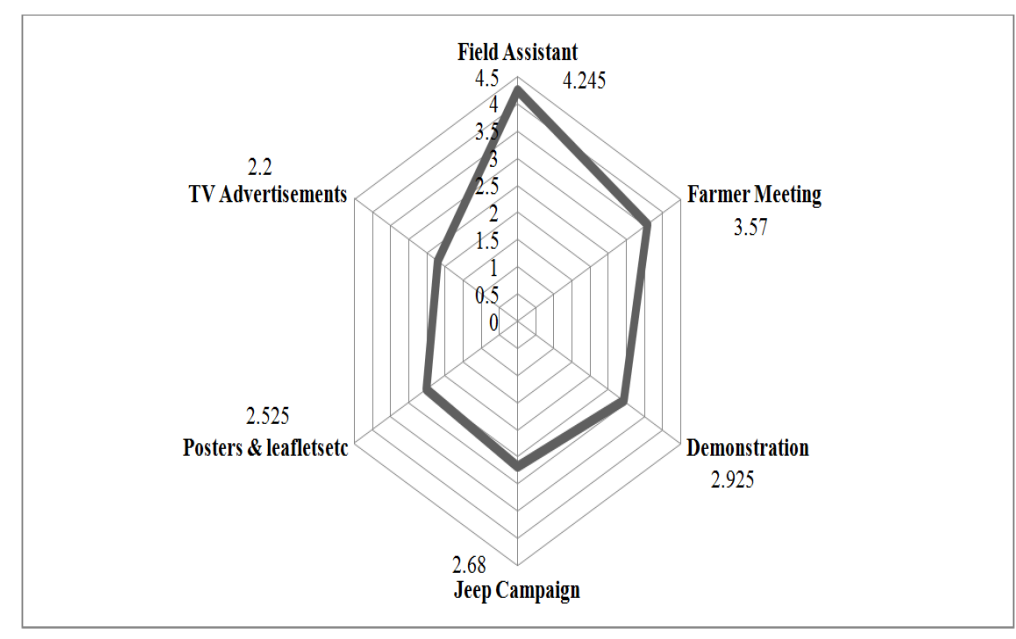

Based on a 5-Point likert scale where 5-Very Important, 4-Important,

3-Average, 2-Not so important, 1-Useless

\section{Figure 4: Farmers' Preference Regarding Promotional} Activities for Pesticide Products

This figure 4 shows the promotional mix preferred by the farmers. According to farmers, field assistant was the most important promotional tool for pesticide products. As most of the pesticide companies deploy their field assistant in 
territories who created word of mouth which affects the farmers well. Farmers meeting was preferred as important by some farmers because such kind of meeting is organized by various pesticide companies in villages to promote their products. Among all, field assistant was preferred as the most important tool because farmers got face to face interaction with them.

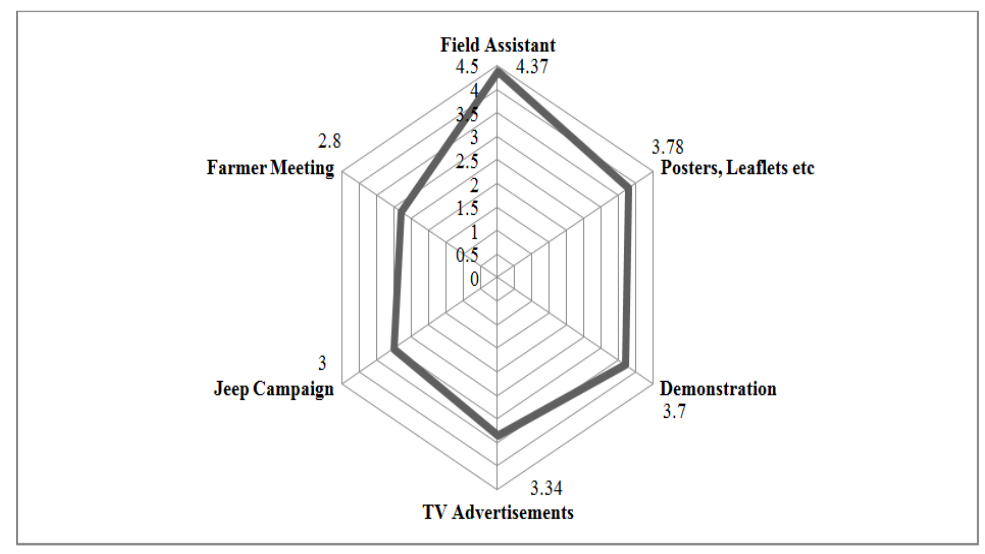

Based on a 5-Point likert scale where 5-Very Important, 4-Important, 3-Average, 2-Not so important, 1-Useless

Figure 5: Distributors' Preference Regarding Promotional Activities for Pesticide Products

As shown in figure 5 field assistant was preferred as most important by distributors also as field assistant first contacted distributors they have to maintain good relations with them because they are the face of any company for distributors. Poster, leaflets etc was considered as important by distributors because generally, they stick posters on their shops which plays important role in promotion.

\section{CONCLUSIONS}

Pesticides play a very important role in crop protection but in today' s scenario, pesticide marketing has more become push marketing. Pesticide companies want to sell their products irrespective of the need of the crops and farmers. The findings of this research show the awareness level of pesticides among farmers. If the companies improve awareness level of their products among farmers then they get to know the exact benefit of that product and then they will purchase that product automatically. So the findings of this research could help companies in a great way. The findings of this research also show the preferences of farmers for the source of information so the companies can focus more on that factors which are preferred more by the farmers. This study also reveals the perception of farmers and distributors for the promotional activities. For both farmers and distributors field assistant is the most important tool for the promotion of pesticide products so companies can deploy their field assistants who are well equipped with knowledge so they can influence the stakeholders more. So it can be concluded that this study could help the pesticide companies to formulate the marketing strategy of their products so that they can convert their marketing from push marketing to pull marketing. 


\section{REFERENCES}

1. A Report on Indian Agrochemicals Industry FICCI (2016). Next Generation Indian Agriculture-Role of Crop Protection Solutions.

2. Lansink, A. O., \& Oudelansink, A. (2004). Non-Parametric Production Analysis of Pesticides Use in the Netherlands. Journal of Productivity Analysis, 21(1),49-65

3. Maroni et al. (2005). Risk assessment and management of occupational exposure to pesticides in agriculture. La Medicina del lavoro, 97(2), 430-437.

4. Alapati, P., \& Shaik, K. S. Improving Farmer's Knowledge On Indigenous Practice Of Spraying Pesticides In Grape Garden.

5. Wauchope, R. D. 1978. The Pesticide Content of Surface Water Draining from Agricultural Fields-A Review 1. J. Environ. Qual. 7: 459-472.

6. Wilson, C. and Tisdell, C. (2001). Why farmers continue to use pesticides despite environmental, health and sustainability costs. Ecological economics, 39(3), 449-462. 